\title{
Effect of Peer-Assisted Learning on Enhancing Clinical Research Skills Among Medical Students: Students' and Tutors' Perceptions
}

\author{
Abdulkarim A Jawhari (D) \\ Maha A Safhi' \\ Mawadah M Magadmi' \\ Rajwa H Alobaidi' \\ Khaled M Alghamdi' \\ Reem N Basyouni' \\ Omar M Saggaf' \\ Murad A Yasawy $\mathbb{D}^{2}$ \\ Rania M Magadmi (1D ${ }^{3}$ \\ 'Faculty of Medicine, King Abdulaziz \\ University, Jeddah, Saudi Arabia; ${ }^{2}$ Faculty of \\ Medicine, Ibn Sina College, Jeddah, Saudi \\ Arabia; ${ }^{3}$ Department of Pharmacology, \\ Faculty of Medicine, King Abdulaziz \\ University, Jeddah, Saudi Arabia
}

\begin{abstract}
Purpose: Research methodology is an essential part of evidence-based medicine. Many educational programs include clinical research methodology within their curriculum. Moreover, students' preferences for learning methods are different than before, as they now prefer alternative methods, such as peer teaching. Peer-assisted learning enhances students' tutoring skills. Thus, the current study aimed to evaluate the effect of peer teaching on enhancing clinical research skills.
\end{abstract}

Participants and Methods: Peer-assisted learning was evaluated during a four-week online research methodology course designed for medical students at King Abdulaziz University. A total of 121 students' and 38 tutors' attitudes and perceptions of peer teaching were evaluated using a self-administered questionnaire. The effectiveness of peer teaching was assessed using pre- and post-course knowledge tests. Chi-square was used to assess the association of qualitative data, and Mann-Whitney $U$-test and Wilcoxon rank test were used as nonparametric tests for the variables that were not normally distributed.

Results: The post-course knowledge score was significantly higher than the pre-test score. Students had a positive perception of peer-assisted learning. Over $90 \%$ of the students preferred peer-assisted learning to traditional teaching. Similarly, the tutors had significantly positive perceptions of peer-assisted teaching. Younger students who had higher post-test mean knowledge scores had a good perception of peer teaching.

Conclusion: The current study demonstrates students' and tutors' positive perceptions of peer-assisted learning as well as the effectiveness of peer learning. Medical schools should pay more attention to students and prepare them for peer-teacher roles.

Keywords: peer-assisted learning, medicine, clinical, methodology, education

\section{Introduction}

Research methodology is one of the most dynamic and important fields in medicine. It is widely considered that research is the cornerstone of evidence-based medical practice. ${ }^{1-3}$ Recently, Dalbhi et al conducted a cross-sectional study in Saudi Arabia to investigate physicians' difficulties with conducting clinical research. They found that the difficulty score decreased among physicians who had attended more research methodology workshops. ${ }^{4}$ Thus, many educational institutes have included clinical research methodology courses in their curriculum. ${ }^{5}$ However, medical students may face problems managing their time between their busy academic schedules and conducting clinical research. ${ }^{6-8}$ Moreover, during the past decade, the learning attitudes and preferences of medical students have changed, as studies
Correspondence: Abdulkarim A Jawhar Faculty of Medicine, King Abdulaziz University, Jeddah, 23212, Saudi Arabia Tel +966559977079

Email Kremjohari@gmail.com 
have shown that they no longer like didactic teaching methods. Instead, they prefer interactive learning, selfdirected learning, and peer-assisted learning (PAL) approaches. 9,10 Taken together, this prompts the need to explore effective ways of teaching this challenging subject by creating a conducive learning environment.

International interest in PAL in medical education has been increasing for more than a decade. ${ }^{11}$ PAL is defined as the practice of students teaching other students. ${ }^{12}$ A systematic review showed that PAL achieves learner outcomes that are comparable to those produced by faculty-based teaching and it has beneficial effects on students' and tutors' learning outcomes. ${ }^{13}$ Additionally, students report that they have more emotional support and reassurance from their senior peers. ${ }^{14}$

A study that was conducted to determine students' perceptions of PAL found that they recognize the unique and important role of PAL in undergraduate medical education and its importance for their professional development. $^{15}$ However, another study showed a divergence in students' responses about implementing PAL into the curriculum in the form of peer-led seminars. The study found that most of the learners did not trust their peers in the teaching process. ${ }^{16}$ However, it is worth mentioning that the majority of the student tutors reported experiencing personal and professional development, and that they improved their collaborative, communication, tutoring, and presentation skills as well as their confidence. $^{16}$

Although the Saudi government strongly encourages research by providing financial support and national and international opportunities, ${ }^{17,18}$ the level of research productivity is still expected to rise. Given the fact that the effectiveness of using PAL in elective courses has not been extensively studied, this study aimed to evaluate its effect on enhancing clinical research skills. Taking into consideration that PAL is a two-way process, the perceptions of the students and the tutors regarding their experience of PAL in clinical research methodology courses was also assessed. This is the first study in Saudi Arabia to evaluate the influence of PAL on research skills and students' and tutors' opinions.

\section{Materials and Methods}

\section{Course Design and Course Training}

In June 2020, a four-week elective online research methodology course was conducted for medical students at King
Abdulaziz University, Jeddah, Saudi Arabia. It was a fullday 4-week course to teach students about study designs, how to write a research paper, basic analysis, and publication while conducting their research. The objectives, schedule, content, and presentations of the course were developed by senior medical students and revised by professional faculty members. Moreover, the senior medical students (hereafter called tutors) had previous research experience and were formally trained to be a student tutor who acknowledged students' questions and concerns during the course. Upon successfully completing the course about clinical research, the students were considered research tutors. Each tutor was assigned a group of 4-5 students; together, these groups comprised the team of students for which the tutors wrote a full manuscript that answered a research question, while being supervised by a consultant physician (principal investigator). The course had an alternating format throughout the day, providing live video conferencing lectures on the different aspects of clinical research and small group sessions/workshops where student would apply and practice the knowledge given during lectures. Although some of the questionnaires given during the course collected students' or tutors' names, the students were told that all answers would be private and access to the data would be given to only few of this research's authors. Further, all the names were in code format and were treated in a highly confidential matter.

\section{Study Aim, Design, and Participants}

The study aimed to evaluate the effect of PAL on the students' clinical research skills and to assess not only the students' perceptions of PAL but also the peer tutors' opinions of the teaching process. This cross-sectional study was conducted among third-, fourth-, and fifth-year medical students who attended an elective online research methodology course during June 2020. The students who filled an application to join the course were recruited for this study. The total number of students who were accepted in the course was 177 students, 155 of them have completed pre- and post-course test, and 121 students have successfully completed the perception questionnaire.

\section{Sample Size}

The required sample size was determined by the OpenEpi software using the formula that calculates the percentage of the frequency in a population. At the $95 \%$ confidence level and with the hypothesized percentage of the 
frequency of the outcome factor in the population being $50 \%$, the required sample size was $120 .{ }^{19}$

\section{Study Instrument}

Before each session, the students had 10 minutes to take an electronic test with 20 multiple-choice questions that addressed their basic knowledge about clinical research. Each answer was rated as follows: $1=$ the correct answer and $0=$ "I don't know" or the wrong answer (pre-test). Then, the teaching sessions began. These were followed by a posttest that was completed by the students, as shown in Figure 1.

At the end of the clinical research course, two selfadministered questionnaires were given to the participants to assess their perceptions of PAL: one was for the students and the other was for the tutors. The questionnaires were adapted and modified based on previously published studies. ${ }^{16,20-22}$ Each questionnaire contained demographic data questions related to the students'/tutors' perceptions of PAL. For the descriptive statistics, the responses to the items were scored on a Likert scale, with potential rankings ranging from 5 (strongly agree) to 1 (strongly disagree). Then, the answers were transformed into codes to calculate the total perception. The "strongly agree" and "agree" responses were coded as a score of 1 , while the "neutral," "disagree," and "strongly disagree" responses were given a score of 0 . Thus, the total score for the students' and tutors' questionnaires ranged from $0-20$ and $0-7$, respectively. If the score was more than $75 \%$ of the total possible score, it was considered a good perception; if less, it was considered a poor perception. In addition to this, an open-ended section was provided for both the tutors and students to allow them to express their opinions about the strengths and weaknesses of peer learning.

\section{Statistical Analysis}

The data were collected, tabulated, and statistically analyzed using an IBM personal computer and IBM SPSS Statistics for Windows version 19 (IBM Corp., Armonk, NY, USA). For the descriptive statistics, the quantitative data were presented in the form of the mean, standard deviation, and range, and the qualitative data were presented in thematic forms. Analytical statistics were used to determine the possible association between the studied factors and the targeted outcome. The tests of significance included the following: (1) the chi-square test, which was used to examine the association between two qualitative variables; (2) Fisher's exact test, which was employed for $2 \times 2$ contingency tables when the expected cell count of more than $25 \%$ of cases was less than 5; (3) the Mann-Whitney $U$-test (nonparametric test), which was used to compare two groups of quantitative variables that were not normally distributed; (4) the Kruskal-Wallis test, which was employed (nonparametric test) to compare three or more groups of quantitative variables that were not normally distributed; and (5) the Wilcoxon signed rank test (nonparametric test), which was used to compare two related groups of quantitative variables that were not normally distributed. A $p$-value of $<0.05$ was considered statistically significant.

\section{Results \\ Students' Demographics}

As shown in Table 1, 121 students completed the questionnaire that assessed their perceptions of PAL. Their

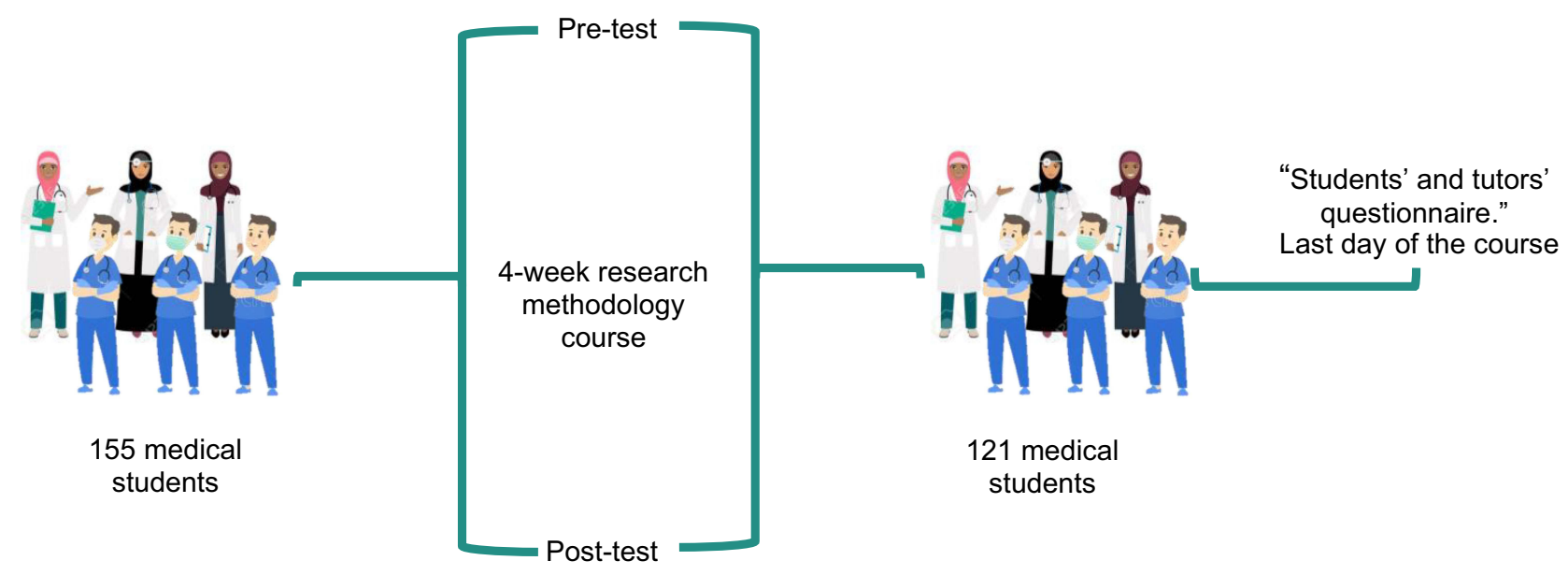

Figure I The methodology of the study. 
Table I Students' Demographic Data $(N=121)$

\begin{tabular}{|c|c|c|}
\hline \multicolumn{2}{|l|}{ Characteristics } & $\begin{array}{c}\text { Frequency } \\
\text { (Percentage) }\end{array}$ \\
\hline \multicolumn{2}{|c|}{ Age/Year (Mean $\pm S D)$} & $22 \pm 1$ \\
\hline \multirow[t]{2}{*}{ Gender } & Male & $42(34.7)$ \\
\hline & Female & $79(65.3)$ \\
\hline \multirow[t]{2}{*}{ Nationality } & Saudi & $115(95)$ \\
\hline & Non-Saudi & $6(5)$ \\
\hline \multirow[t]{3}{*}{ Academic Year } & Third Year & $65(53.7)$ \\
\hline & Fourth Year & $35(28.9)$ \\
\hline & Fifth Year & $21(17.4)$ \\
\hline \multirow{2}{*}{$\begin{array}{l}\text { Previous Research } \\
\text { Courses }\end{array}$} & Yes & $7(5.8)$ \\
\hline & No & $114(94.2)$ \\
\hline \multirow{4}{*}{$\begin{array}{l}\text { Previous Research } \\
\text { Experience }\end{array}$} & Yes & $42(34.7)$ \\
\hline & Data Collector & $34(80)$ \\
\hline & Co-Author & $8(20)$ \\
\hline & No & $79(65.3)$ \\
\hline \multirow{2}{*}{$\begin{array}{l}\text { Research } \\
\text { Methodology } \\
\text { Preferences }\end{array}$} & $\begin{array}{l}\text { Better when given by } \\
\text { peer tutors }\end{array}$ & II5 (95.0) \\
\hline & $\begin{array}{l}\text { Better when given via } \\
\text { traditional teaching }\end{array}$ & $6(5.0)$ \\
\hline
\end{tabular}

Abbreviation: SD, standard deviation.

mean age was $22 \pm 1$ years, $79(65.3 \%)$ were female and 42 (34.7\%) were male, and 95\% were Saudis. The academic year was distributed as follows: $53.7 \%$ were third-year students, $28.9 \%$ were fourth-year students, and $17.4 \%$ were in their fifth year.

The majority of the students $(94.2 \%)$ had not taken a course in how to conduct scientific research. Furthermore, only one-third (34.7\%) had previous research experience; of these, $80 \%$ had participated as a data collector and $20 \%$ had participated as a co-author. Most of the respondents $(95 \%)$ reported that they thought that the research methodology course was better when given by students (ie, the peer tutors).

\section{Students' Pre- and Post-Test Knowledge}

A total of 155 students completed the pre- and post-tests that evaluated their knowledge of clinical research methodology before and after taking the course. The students' mean knowledge scores in the post-test were significantly higher than those in the pre-test for all knowledge items (19 \pm 4 vs $12 \pm 5$, respectively, $p=0.001)$ (Figure 2 ).

\section{Students' Perceptions of Peer Teaching}

Regarding the students' perceptions of the tutors' knowledge and skills, 94.2\% agreed that the tutors' knowledge was appropriate for the required level of teaching, and $92.6 \%$ agreed that their tutor provided appropriate guidance that targeted their needs. Most of the participants (97.5\%) thought that the tutor was approachable and happy to answer questions and that he/she created a welcoming learning environment. In general, $98.3 \%$ felt that they generally and adequately benefited from this experience/opportunity. Regarding the learners' general perceptions of peer teaching and mentoring, 97.5\% thought that PAL is an effective teaching strategy and $90.1 \%$ preferred being taught by a peer tutor rather than via traditional teaching. Table 2 shows the answers regarding the students' perception of PAL.

As for the students' opinions about the PAL experience, 99\% responded that they would recommend this course to colleagues. When further questioned about if PAL would be useful for other activities/skills, 118 $(97.5 \%)$ answered "yes" for the research methodology course, $105(86.8 \%)$ responded that they would prefer peer tutors to teach them clinical skills, and 108 (89.3) answered "yes" regarding extra-curricular activities. The other perceptions are shown in Table 3. Furthermore, the students' most frequent opinions about the strengths and weaknesses of PAL are shown in Figure 3.

Regarding the participants' perceptions of PAL, 110 of the students had a good perception (90.9\%), while only 11 students had a poor perception. As shown in Table 4, a significantly higher percentage of students who were younger, in the third year, and who had a higher post-test mean knowledge score had a good perception of peer teaching. On the other hand, a non-significant relationship was found between the perception of peer teaching and the participants' gender, experience of previous research, and pre-test mean knowledge score.

\section{Tutors' Demographic Data}

The mean age of the tutors who participated in the PAL course was 22 years, three-quarters were female, and half were in the fifth academic year (Table 5). Most of the participants (97.4\%) had engaged in previous courses in how to conduct scientific research, and $89.2 \%$ had previously attended the four-week methodology research course. The mean number of studies that they participated 


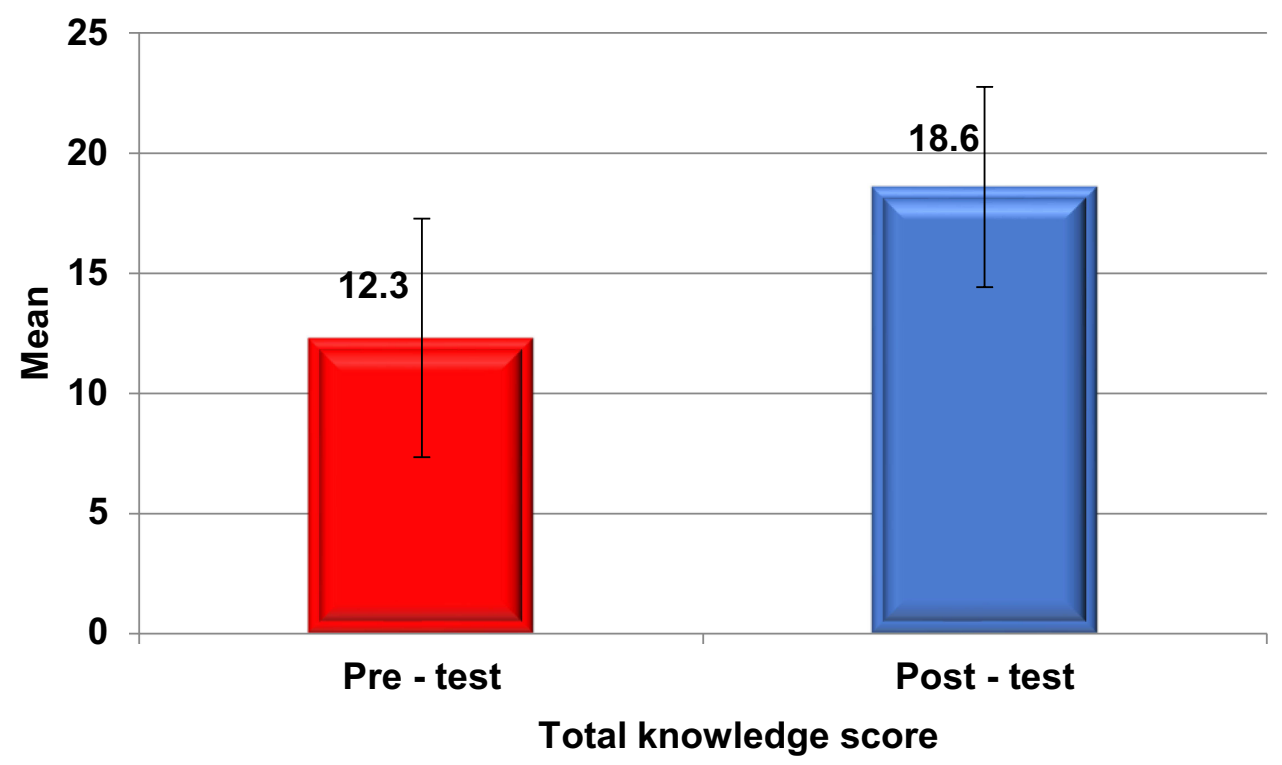

Figure 2 Mean (standard deviation) of the total knowledge score in the pre- and post-tests Wilcoxon signed rank test $=8.8 \mathrm{I}, p$-value $=0.00 \mathrm{I}$.

in was $3 \pm 1$. All of the tutors thought that this course was better when given by students.

\section{Tutors' Perceptions of Peer Teaching}

As for the tutors' perceptions of the teaching and mentoring experience, $94.7 \%$ reported that they had the opportunity to consolidate their own knowledge, $92.1 \%$ said that being a peer tutor increased their confidence in their teaching and presentation skills, and $84.2 \%$ reported that they had a better understanding of teamwork and roles within the team (Tables 6 and 7).

Interestingly, $65.5 \%$ of the tutors thought that being a peer teacher was a good idea. The strengths and weaknesses of the PAL experience from the tutors' point of view are shown in Figure 4, and "having better communication skills" was the most frequently reported strength (44.7\%).

\section{Discussion}

Several studies of medical education have suggested that PAL is an acceptable and beneficial education strategy. Students can develop new skills and knowledge through active learning and support from their senior peers. ${ }^{23}$ A previous study conducted at Birjand University of Medical Sciences that examined the educational methods supported the concept that PAL is more effective for students' learning and knowledge retention. ${ }^{24}$ Participation in PAL is considered an effective and efficient way to introduce and foster core professional skills that may not be included in formal medical professional curricula. ${ }^{25,26}$ Learning with peers can also create a safer learning environment, which lacks the barriers that exist between the tutor and students to some extent. ${ }^{27,28}$ Tutors or senior students can also provide motivation for younger students more than senior staff, which will eventually affect the educational process. ${ }^{10}$ In the PAL environment, students are more familiar with the learning requirements of their senior peers, ${ }^{23,29,30}$ and senior students can provide them with information, good quality demonstrations, and feedback for every task and clinical skills station. ${ }^{10}$

In the present study, the PAL that was given during the research methodology course had a significant effect on the students' knowledge. This observation can be explained in different ways. Because of the proximity of the students and peer tutors, the tutors are more likely to understand which concepts the students may find difficult, and they can explain them to the students in a simpler way. This social proximity is thought to enable the students to express their difficulties more comfortably, to feel relaxed, and to gain confidence through observing a peer in a teaching role. ${ }^{29,30}$

Moreover, this study found that students with a good perception of PAL had significantly better post-test results compared to those who had a poor perception. A comfortable educational environment and satisfactory learning style may be the main factors of these high scores. ${ }^{31-33}$ The idea of peer teaching has spread widely in the past few decades. ${ }^{34}$ As PAL has a long history, students have been engaged in different activities/courses that are supervised by their senior peers, and the fact that 
Table 2 Students' Perceptions of Peer-Assisted Teaching ( $N=121)$

\begin{tabular}{|c|c|c|c|c|c|c|c|c|c|c|c|}
\hline \multirow[t]{2}{*}{ Studied Variables } & \multicolumn{2}{|c|}{$\begin{array}{l}\text { Strongly } \\
\text { Agree }\end{array}$} & \multicolumn{2}{|c|}{ Agree } & \multicolumn{2}{|c|}{ Neutral } & \multicolumn{2}{|c|}{ Disagree } & \multicolumn{2}{|c|}{$\begin{array}{l}\text { Strongly } \\
\text { Disagree }\end{array}$} & \multirow{2}{*}{$\begin{array}{l}\text { Percentage } \\
\quad \text { of } \\
\text { Agreement }\end{array}$} \\
\hline & No. & $\%$ & No. & $\%$ & No. & $\%$ & No. & $\%$ & No. & $\%$ & \\
\hline \multicolumn{12}{|l|}{ Peer Tutors' Knowledge } \\
\hline $\begin{array}{l}\text { The tutor's knowledge was appropriate for the } \\
\text { required level of teaching }\end{array}$ & 71 & 58.7 & 43 & 35.5 & 4 & 3.30 & 1 & 0.80 & 2 & 1.70 & 94.2 \\
\hline $\begin{array}{l}\text { The tutor provided appropriate guidance that targeted } \\
\text { my needs (eg, how to enhance my academic writing) }\end{array}$ & 77 & 63.6 & 35 & 28.9 & 6 & 5.00 & I & 0.80 & 2 & 1.70 & 92.6 \\
\hline \multicolumn{12}{|l|}{ Peer Tutors' Attitude } \\
\hline $\begin{array}{l}\text { The tutor is approachable and happy to answer } \\
\text { questions }\end{array}$ & 108 & 89.3 & 10 & 8.30 & 2 & 1.70 & I & 0.80 & 0 & 0.00 & 97.5 \\
\hline The tutor creates a welcoming learning environment & 104 & 86.0 & 14 & 11.6 & I & 0.80 & 2 & 1.70 & 0 & 0.00 & 97.5 \\
\hline $\begin{array}{l}\text { Overall, I feel that I adequately benefited from this } \\
\text { experience/opportunity }\end{array}$ & 93 & 76.9 & 26 & 21.5 & 2 & 1.70 & 0 & 0.00 & 0 & 0.00 & 98.3 \\
\hline \multicolumn{12}{|l|}{ Peer-Teaching Preferences } \\
\hline Peers can perform well in the role of tutors & 76 & 62.8 & 39 & 32.2 & 3 & 2.50 & 3 & 2.50 & 0 & 0.00 & 95 \\
\hline $\begin{array}{l}\text { Peer-assisted teaching is more beneficial for the student } \\
\text { than the tutor }\end{array}$ & 41 & 33.9 & 32 & 26.4 & 42 & 34.7 & 6 & 5.00 & 0 & 0.00 & 60.3 \\
\hline \multicolumn{12}{|c|}{ Learners' General Perceptions of Peer Teaching and Mentoring } \\
\hline Peer-assisted teaching is an effective teaching strategy & 85 & 70.2 & 33 & 27.3 & 2 & 1.70 & I & 0.80 & 0 & 0.00 & 97.5 \\
\hline $\begin{array}{l}\text { I prefer being taught by a peer tutor than via traditional } \\
\text { teaching }\end{array}$ & 80 & 66.1 & 29 & 24.0 & 11 & 9.10 & I & 0.80 & 0 & 0.00 & 90.1 \\
\hline $\begin{array}{l}\text { I am more willing to engage in sessions taught by a peer } \\
\text { tutor than during traditional teaching }\end{array}$ & 81 & 66.9 & 33 & 27.3 & 5 & 4. 10 & 2 & 1.70 & 0 & 0.00 & 94.2 \\
\hline $\begin{array}{l}\text { I feel more confident learning from a peer tutor } \\
\text { compared to traditional teaching }\end{array}$ & 80 & 66.1 & 28 & 23.1 & 12 & 9.90 & 1 & 0.80 & 0 & 0.00 & 89.3 \\
\hline $\begin{array}{l}\text { The peer-assisted teaching that I received in this course } \\
\text { is sufficient to prepare me to start my own research }\end{array}$ & 58 & 47.9 & 48 & 39.7 & 11 & 9.10 & 4 & 3.30 & 0 & 0.00 & 87.6 \\
\hline Interested in becoming a peer tutor & 53 & 43.8 & 28 & 23.1 & 26 & 21.5 & 12 & 9.90 & 2 & 1.70 & 66.9 \\
\hline
\end{tabular}

they have tried and been involved in this way of teaching for different aspects has had direct and indirect effects on their general perception of the peer-teaching method. The popularity of this method among students may have unconsciously caused the students to overestimate PAL and this may have led to the high percentage of the good perception.

This study set out with the aim of assessing not only the students' perceptions of PAL but also the peer tutors' opinions of the teaching process. The study found that the majority of tutors had the opportunity to consolidate their knowledge. In accordance with the present results, previous studies of the psychology of memory retrieval have demonstrated that teaching deepens and enhances one's understanding of the content being taught. This could be related to the organization of the information in the tutor's mind and retrieval of the information during the teaching session. ${ }^{16,34}$

It was also found that a considerable number of tutors felt confident. This was expected since each tutor 
Table 3 Frequency Distribution of the Students' Opinions of Peer Teaching for Other Activities/Skills

\begin{tabular}{|l|c|c|c|c|}
\hline \multirow{2}{*}{$\begin{array}{l}\text { Activities/Skills for Which Peer- } \\
\text { Assisted Teaching Would be }\end{array}$} & \multicolumn{2}{|c|}{ Yes } & \multicolumn{2}{c|}{ No } \\
\cline { 2 - 5 } Useful & No. & $\%$ & No. & $\%$ \\
\hline SMLE & 92 & 76.0 & 29 & 24.0 \\
USMLE & 89 & 73.6 & 32 & 26.4 \\
Research Methodology & 118 & 97.5 & 3 & 2.50 \\
Clinical Skills & 105 & 86.8 & 16 & 13.2 \\
Communication Skills & 101 & 83.5 & 20 & 16.5 \\
Faculty's Tutorials & 8 & 81.0 & 23 & 19.0 \\
Extra-Curricular Activity & 108 & 89.3 & 13 & 10.7 \\
\hline
\end{tabular}

Abbreviations: SMLE, Saudi Medical Licensure Examination; USMLE, United States Medical Licensure Examination.

completed a training course that contained theoretical knowledge about research, taught them how to deal with future situations that they might face during the course, and taught them how to be a good mentor. Additionally, periodical feedback was received from the students, which helped the tutor to meet their learning needs and improve their teaching skills. Moreover, each student felt supported and prepared because they had a senior assistant and a consultant to review their academic writing and to acknowledge their questions. However, this outcome is contrary to some previous studies that found that peer tutors experience many concerns and struggle with anxiety about their ability to teach. ${ }^{34,35}$ One interesting finding is that more than three-quarters of the tutors reported that being a peer tutor made them consider an academic career in the future. This emphasizes the importance of PAL for tutors to pursue an academic teaching career.

The thematic analysis of the students' and tutors' feedback identified the strengths and weaknesses of their PAL experience. They reported many strengths of PAL. Most were related to the easy and useful communication between the tutor and students without any barriers; the closer the tutor to the students' age, the more they benefited. In addition, this helps the tutor to be more

Table 4 Factors Affecting Students' Perceptions of Peer Teaching

\begin{tabular}{|c|c|c|c|c|}
\hline \multirow[t]{2}{*}{ Characteristics } & & \multicolumn{2}{|c|}{ Perceptions of Peer Teaching } & \multirow[t]{2}{*}{$P$-value } \\
\hline & & $\begin{array}{l}\text { Good Perception } \\
\qquad(\mathbf{N}=|| 10)\end{array}$ & $\begin{array}{l}\text { Poor Perception } \\
\qquad(\mathbf{N}=\text { II })\end{array}$ & \\
\hline \multicolumn{2}{|l|}{ Age/Years (Mean $\pm S D$ ) } & $21.6 \pm 1.05$ & $23.6 \pm 1.02$ & 0.001 \\
\hline \multirow[t]{2}{*}{ Gender } & Male & $38(34.5)$ & $4(36.4)$ & 0.904 \\
\hline & Female & $72(65.5)$ & $7(63.6)$ & \\
\hline \multirow[t]{3}{*}{ Educational Level } & Third year & $63(57.3)$ & $2(18.2)$ & 0.014 \\
\hline & Fourth year & $31(28.2)$ & $4(36.4)$ & \\
\hline & Fifth year & $16(14.5)$ & $5(45.5)$ & \\
\hline \multirow[t]{2}{*}{ Experience of Previous Research } & Yes & $39(35.5)$ & $3(27.3)$ & 0.746 \\
\hline & No & $71(64.5)$ & $8(72.7)$ & \\
\hline \multirow{4}{*}{$\begin{array}{l}\text { Knowledge and Improvement } \\
\text { Level }\end{array}$} & Knowledge Pre-Test & & & 0.542 \\
\hline & $($ Mean $\pm S D)$ & $12.4 \pm 5.08$ & $11.4 \pm 4.52$ & \\
\hline & $\begin{array}{l}\text { Knowledge Post-Test } \\
(\text { Mean } \pm S D)\end{array}$ & $19.1 \pm 3.24$ & $13.4 \pm 7.52$ & 0.006 \\
\hline & $\begin{array}{l}\text { Improvement Level } \\
\text { (Knowledge Post-Test- Knowledge Pre- } \\
\text { Test) }\end{array}$ & 6.7 & 2 & $\begin{array}{c}\text { No } \\
P \text {-value }\end{array}$ \\
\hline
\end{tabular}

Abbreviation: SD, standard deviation. 


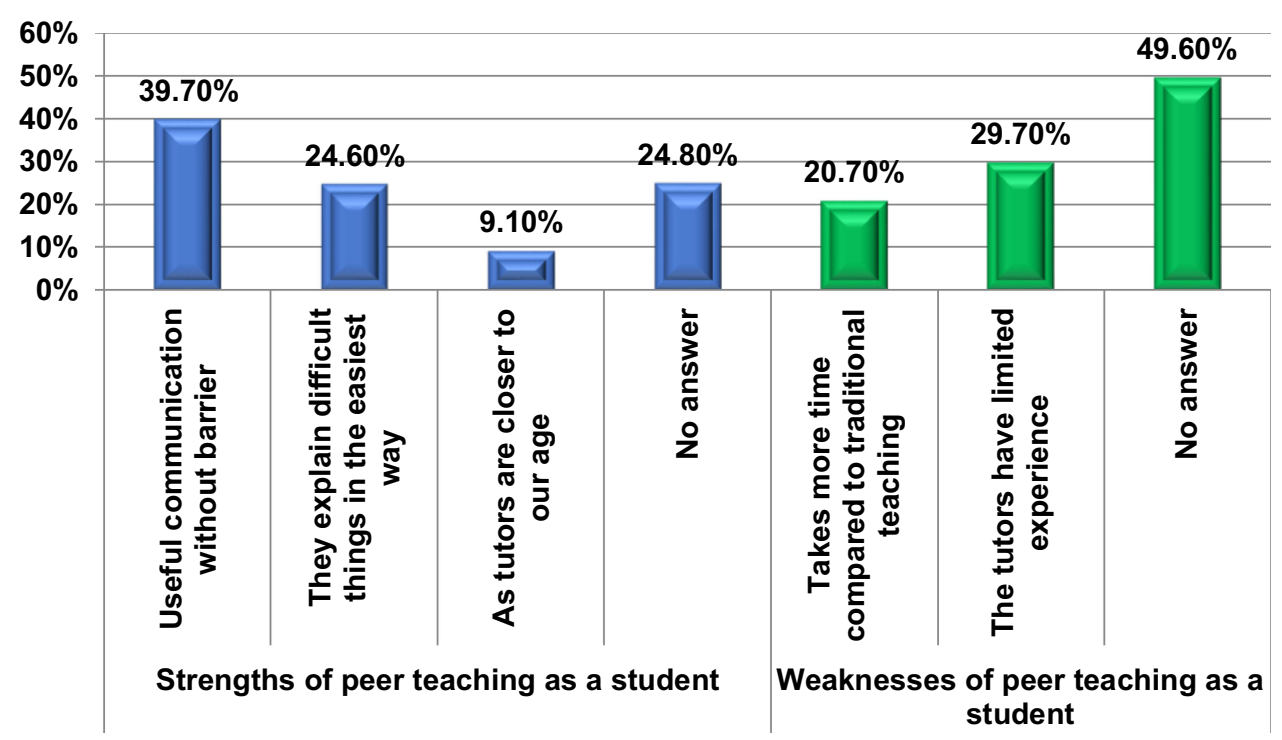

Figure 3 Percentage distribution of the students' most frequent answers to the open questions.

approachable and to explain complicated topics in provides a more comprehensive support network than a simpler way. Many studies of PAL have highlighted the same findings. ${ }^{13,21}$ This provides more insight into the special social atmosphere that PAL offers; that is, it more traditional systems. ${ }^{21}$

However, the lack of experience is the most common weakness of PAL from both the students' and tutors'

Table 5 Tutor's Sociodemographic Data

\begin{tabular}{|c|c|c|}
\hline \multicolumn{3}{|l|}{ Characteristics $(n=38)$} \\
\hline Age/Year & Mean $\pm S D$ & $22 \pm 1$ \\
\hline No Previous Research Experience & Mean $\pm S D$ & $3 \pm 1$ \\
\hline \multirow[t]{2}{*}{ Gender } & Male & $8(21.1 \%)$ \\
\hline & Female & 30 (78.9\%) \\
\hline \multirow[t]{2}{*}{ Nationality } & Saudi & $38(100.0 \%)$ \\
\hline & Non-Saudi & $0(0.0 \%)$ \\
\hline \multirow[t]{3}{*}{ Academic Year } & Fourth Year & $18(47.4 \%)$ \\
\hline & Fifth Year & $19(50.0 \%)$ \\
\hline & Sixth Year & I $(2.6 \%)$ \\
\hline \multirow[t]{4}{*}{ Previous Research Courses } & Yes 37 & (97.4\%) \\
\hline & Four-week methodology research course & 34 (91.9\%) \\
\hline & Other research summer school & $3(8.1 \%)$ \\
\hline & No & I $(2.6 \%)$ \\
\hline \multirow[t]{2}{*}{ Research Methodology Preferences } & Better when given by peer tutors & $38(100.0 \%)$ \\
\hline & Better when given via traditional teaching & $0(0.0 \%)$ \\
\hline
\end{tabular}

Abbreviation: SD, standard deviation. 
Table 6 Frequency Distribution of the Tutors' Perceptions of Peer-Assisted Teaching and Mentoring

\begin{tabular}{|c|c|c|c|c|c|c|c|c|c|c|c|}
\hline \multirow[t]{2}{*}{ Studied Variables } & \multicolumn{2}{|c|}{$\begin{array}{l}\text { Strongly } \\
\text { Agree }\end{array}$} & \multicolumn{2}{|c|}{ Agree } & \multicolumn{2}{|c|}{ Neutral } & \multicolumn{2}{|c|}{ Disagree } & \multicolumn{2}{|c|}{$\begin{array}{l}\text { Strongly } \\
\text { Disagree }\end{array}$} & \multirow[t]{2}{*}{$\begin{array}{l}\text { Percentage of } \\
\text { Agreement }\end{array}$} \\
\hline & No. & $\%$ & No. & $\%$ & No. & $\%$ & No. & $\%$ & No. & $\%$ & \\
\hline I had the opportunity to consolidate my knowledge & 25 & 65.8 & 10 & 26.3 & 2 & 5.30 & 1 & 2.60 & 0 & 0.00 & 94.7 \\
\hline $\begin{array}{l}\text { Being a tutor has increased my confidence in my } \\
\text { tutoring and presentation skills }\end{array}$ & 21 & 55.3 & II & 28.9 & 6 & 15.8 & 0 & 0.00 & 0 & 0.00 & 92.1 \\
\hline $\begin{array}{l}\text { I have a better understanding of teamwork and the } \\
\text { roles within the team }\end{array}$ & 17 & 44.7 & 14 & 36.8 & 6 & 15.8 & I & 2.60 & 0 & 0.00 & 84.2 \\
\hline I am a better role model to my peers & 21 & 55.3 & 14 & 36.8 & 3 & 7.90 & 0 & 0.00 & 0 & 0.00 & 92.1 \\
\hline I have developed both personally and professionally & 6 & 15.8 & 20 & 52.6 & 12 & 31.6 & 0 & 0.00 & 0 & 0.00 & 68.4 \\
\hline $\begin{array}{l}\text { Being a tutor has made me consider an academic } \\
\text { career in the future }\end{array}$ & 15 & 39.5 & 18 & 47.4 & 5 & 13.2 & 0 & 0.00 & 0 & 0.00 & 86.8 \\
\hline $\begin{array}{l}\text { I think the students benefited from my teaching and } \\
\text { mentoring experience }\end{array}$ & 10 & 26.3 & 9 & 23.7 & 5 & 13.2 & 8 & 21.1 & 0 & 0.00 & 50 \\
\hline $\begin{array}{l}\text { I had support from faculty or other peers (eg, } \\
\text { senior assistants) }\end{array}$ & 23 & 60.5 & 14 & 36.8 & 1 & 2.60 & 0 & 0.00 & 0 & 0.00 & 97.4 \\
\hline $\begin{array}{l}\text { Overall, I feel I was adequately prepared for this } \\
\text { role }\end{array}$ & 22 & 57.9 & 12 & 31.6 & 4 & 10.5 & 0 & 0.00 & 0 & 0.00 & 89.5 \\
\hline $\begin{array}{l}\text { Peer teaching is more beneficial for the student } \\
\text { than the tutor }\end{array}$ & 16 & 42.1 & 18 & 47.4 & 4 & 10.5 & 0 & 0.00 & 0 & 0.00 & 89.5 \\
\hline Every medical student should learn how to teach & 13 & 34.2 & 8 & 21.1 & 13 & 34.2 & 4 & 10.5 & 0 & 0.00 & 55.3 \\
\hline
\end{tabular}

perspectives. Interestingly, this is a commonly cited concern about peer teaching in many studies. ${ }^{11,36}$ Indeed, it is usual for peer tutors to be less expert than senior staff, yet they do their best and prepare well to succeed in their role as a tutor. ${ }^{22}$ Therefore, the appropriate preparation and selection of tutors is required to ensure that students benefit from them. ${ }^{37}$
This study has several limitations. First, it included only medical students, which may have affected its applicability to other specialties. Second, the PAL experience occurred in an online setting, not in a formal setting. Third, the participants who had a positive experience of PAL were more likely to complete the surveys and may have exaggerated their responses

Table 7 Frequency Distribution of the Tutors' Opinions of Their Peer-Assisted Teaching Experience

\begin{tabular}{|c|c|c|c|c|c|c|c|c|c|c|c|}
\hline \multirow[t]{2}{*}{ Studied Variables } & \multicolumn{2}{|c|}{$\begin{array}{c}\text { Strongly } \\
\text { Agree }\end{array}$} & \multicolumn{2}{|c|}{ Agree } & \multicolumn{2}{|c|}{ Neutral } & \multicolumn{2}{|c|}{ Disagree } & \multicolumn{2}{|c|}{$\begin{array}{l}\text { Strongly } \\
\text { Disagree }\end{array}$} & \multirow[t]{2}{*}{$\begin{array}{c}\text { Percentage of } \\
\text { Agreement }\end{array}$} \\
\hline & No. & $\%$ & No. & $\%$ & No. & $\%$ & No. & $\%$ & No. & $\%$ & \\
\hline I felt comfortable in my role as a tutor & 12 & 31.6 & 20 & 52.6 & 4 & 10.5 & 2 & 5.30 & 0 & 0.00 & 84.2 \\
\hline I learned a lot about teaching techniques & 16 & 42.1 & 16 & 42.1 & 5 & 13.2 & 0 & 0.00 & 1 & 2.60 & 84.2 \\
\hline $\begin{array}{l}\text { I learned a lot about the subject matter while } \\
\text { teaching }\end{array}$ & 23 & 60.5 & 11 & 28.9 & 3 & 7.90 & 0 & 0.00 & 1 & 2.60 & 89.5 \\
\hline Teaching was stressful and taxing & 4 & 10.5 & 9 & 23.7 & 14 & 36.8 & 5 & 13.2 & 6 & 15.8 & 34.2 \\
\hline $\begin{array}{l}\text { The feedback encouraged me to self-assess and } \\
\text { improve my teaching }\end{array}$ & 21 & 55.3 & II & 28.9 & 4 & 10.5 & 0 & 0.00 & 2 & 5.30 & 84.2 \\
\hline
\end{tabular}




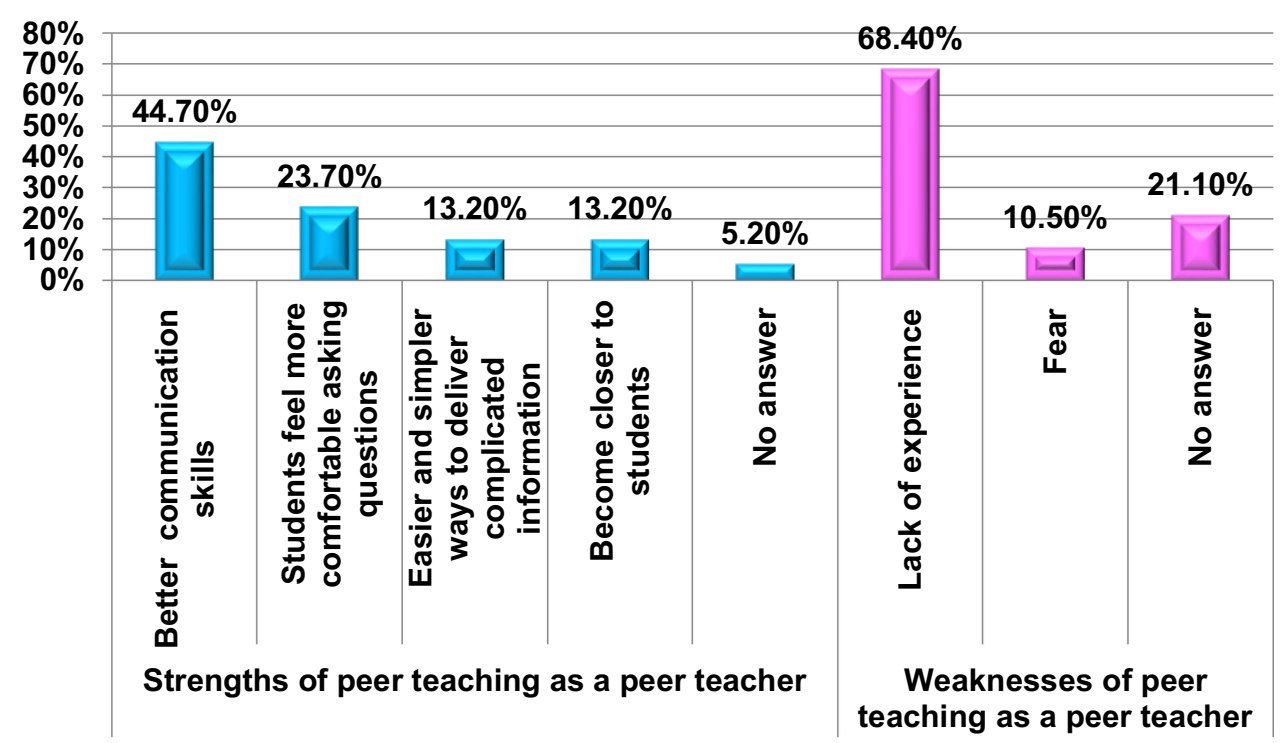

Figure 4 Percentage distribution of the tutors' most frequent answers to the open questions.

about the PAL activities. Finally, there is a lack of evidence about the long-term effect of PAL on their future career, including on their knowledge, skills, professionalism, and so on.

\section{Conclusions}

This study highlights the positive perceptions of PAL from the students' and tutors' perspectives. The majority reported that they developed personally and professionally from this experience. The findings also support the previous literature and encourage the use of PAL in medical education as a competency of the curricula. Every doctor is expected to teach future generations; therefore, medical colleges should pay more attention to the students, prepare them to be peer teachers, and give them every opportunity. Moreover, it would be interesting for future research to follow up the students and tutors to determine if their perceptions of the benefits of PAL change during their postgraduate years.

\section{Abbreviation}

PAL, peer-assisted learning.

\section{Data Sharing Statement}

The datasets used and/or analyzed during the current study are available from the corresponding author on reasonable request.

\section{Ethics Approval and Consent to Participate}

Ethical approval was obtained from The Unit of Biomedical Ethics at King Abdulaziz University
Hospital and each student signed an online consent form to participate in this study (reference no. 322-20). All participants provided informed consent and all methods were carried out in accordance with relevant guidelines and regulations.

\section{Consent for Publication}

Electronic consent was obtained from each participant included in this study.

\section{Acknowledgments}

We would like to thank research summer school road of change for their support during the period of the study, as well as Editage (www.editage.com) for English language editing.

\section{Author Contributions}

All authors contributed to data analysis, drafting or revising the article, have agreed on the journal to which the article will be submitted, gave final approval of the version to be published, and agree to be accountable for all aspects of the work.

\section{Funding}

The study received no specific funding.

\section{Disclosure}

The authors reported no conflicts of interest for this work. 


\section{References}

1. Rahman S, Majumder MAA, Shaban SF, et al. Physician participation in clinical research and trials: issues and approaches. Adv Med Edu Pract. 2011;85. doi:10.2147/AMEP.S14103

2. Nayak BK. Why learn research methodology? Indian J Ophthalmol. 2009;57(3):173. doi:10.4103/0301-4738.49389

3. Boet S, Sharma S, Goldman J, Reeves S. Review article: Medical education research: an overview of methods. Can J Anesth/J Can Anesth. 2012;59:159-170. doi:10.1007/s12630-011-9635-y

4. Al Dalbhi S, Alodhayani A, Alghamdi Y, Alrasheed S, Alshehri A, Alotaibi N. Difficulties in conducting clinical research among healthcare practitioners in Saudi Arabia: a cross-sectional survey. J Family Med Prim Care. 2019;8(6):1877. doi:10.4103/jfmpc.jfmpc_317_19

5. Alshayea A. Scientific Research in the Kingdom of Saudi Arabia: potential for excellence and indicators of underdevelopment. Higher Edu Studies. 2013;3(5). doi:10.5539/hes.v3n5p47

6. Bocar AC. Difficulties encountered by the student-researchers and the effects on their research output. SSRN; 2009. Available from: https://papers.ssrn.com/sol3/papers.cfm?abstract_id=1612050/. doi:10.2139/SSRN.1612050

7. Dadipoor S, Ramezankhani A, Aghamolaei T, Safari-Moradabadi A. Barriers to research activities as perceived by medical university students: a cross-sectional study. Avicenna journal of medicine. 2019:9(1):8-14. doi:10.4103/ajm.AJM_121_18

8. Abushouk AI, Hatata AN, Omran IM, Youniss MM, Elmansy KF, Meawad AG. Attitudes and perceived barriers among medical students towards clinical research: a cross-sectional study in an Egyptian medical school. Journal of Biomedical Education. 2016:Article ID 5490575. doi:10.1155/2016/5490575

9. House JB, Choe CH, Wourman HL, Berg KM, Fischer JP, Santen SA. Efficient and effective use of peer teaching for medical student simulation. The western journal of emergency medicine. 2017:18 (1):137-141. doi:10.5811/westjem.2016.11.32753

10. Khaw C, Raw L. The outcomes and acceptability of near-peer teaching among medical students in clinical skills. Int $J$ Med Edu. 2016;7:189-195. doi:10.5116/ijme.5749.7b8b

11. Secomb J. A systematic review of peer teaching and learning in clinical education. J Clin Nurs. 2008;17(6):703-716. doi:10.1111/ j.1365-2702.2007.01954.x

12. Ladyshewsky RK. Peer-assisted learning in clinical education: a review of terms and learning principles. J Phy Ther Edu. 2000;14 (2):15-22. doi:10.1097/00001416-200007000-00004

13. Yu T-C, Wilson NC, Singh PP, Lemanu DP, Hawken SJ, Hill AG. Medical students-as-teachers: a systematic review of peer-assisted teaching during medical school. Advances in medical education and practice. 2011;2:157-172. doi: 10.2147/AMEP.S14383

14. Christiansen A, Bell A. Peer learning partnerships: exploring the experience of pre-registration nursing students. $J$ Clin Nurs. 2010;19:803-810. doi:10.1111/j.1365-2702.2009.02981.x

15. Aba Alkhail B. Near-peer-assisted learning (NPAL) in undergraduate medical students and their perception of having medical interns as their near peer teacher. Med Teacher. 2015;37(sup1):S33-S39. doi:10.3109/0142159X.2015.1006602

16. AlShareef SM, Aldayel AY, Alghamdi HM, et al. Perceptions on reciprocal peer teaching among medical students as learners and as tutors. Advances in medical education and practice.2019;10:817-827. doi:10.2147/AMEP.S220728

17. Meo S, Hassan A, Usmani A. Research progress and prospects of Saudi Arabia in global medical sciences. European review for medical and pharmacological sciences. 2013;17(24):3265-3271.

18. Al-Bishri J. Evaluation of biomedical research in Saudi Arabia. Saudi Med J. 2013;34(9):954-959.

19. Dean A, Sullivan KM, Soe MM. OpenEpi: open source epidemiologic statistics for public health, version 3.01. Available from: https:// www.openepi.com/Menu/OE_Menu.htm.
20. Bulte C, Betts A, Garner K, Durning S. Student teaching: views of student near-peer teachers and learners. Med Teacher. 2007;29 (6):583-590. doi:10.1080/01421590701583824

21. O'Shaughnessy S. Peer teaching as a means of enhancing communication skills in anaesthesia training: trainee perspectives. Irish J Med Sci. 2018;187(1):207-213. doi:10.1007/s11845-017-1637-5

22. Srivastava TK, Waghmare LS, Mishra VP, Rawekar AT, Quazi N, Jagzape AT. Peer teaching to Foster learning in physiology. J Clin Diagnostic Res. 2015. doi:10.7860/JCDR/2015/15018.6323

23. Chaudhuri A, Ray B, Koner S. To study the effect of peer assisted learning on academic performance and perceived stress scores among first MBBS students in a college of West Bengal.International Journal of Research and Review. 2018:5(11):240-248.

24. Abedini M, Mortazavi F, Javadinia SA, Moonaghi HK. A new teaching approach in basic sciences: peer assisted learning. Procedia Social and Behavioral Sciences. 2013;83:39-43. doi:10.1016/j. sbspro.2013.06.008

25. Dandavino M, Snell L, Wiseman J. Why medical students should learn how to teach. Med Teacher. 2007;29(6):558-565. doi:10.1080/ 01421590701477449

26. Ten Cate O, Durning S. Dimensions and psychology of peer teaching in medical education. Med Teacher. 2007;29(6):546-552. doi:10.1080/01421590701583816

27. Chou CL, Johnston CB, Singh B, et al. A "safe space" for learning and reflection: one school's design for continuity with a peer group across clinical clerkships. Acad Med. 2011;86:1560-1565. doi:10.1097/ACM.0b013e31823595fd

28. Lincoln MA, McAllister LL. Peer learning in clinical education. Med Teacher. 1993;15(1):17-26. doi:10.3109/01421599309029007

29. Bennett D, O'Flynn S, Kelly M. Peer assisted learning in the clinical setting: an activity systems analysis. Adv Health Sci Edu. 2015;20 (3):595-610. doi:10.1007/s10459-014-9557-x

30. Fallaha MA, Pagarkar A, Lucas N. Peer-assisted learning: a medical student perspective. Advances in medical education and practice. 2018;9:143-145. doi:10.2147/AMEP.S160165

31. Ahmed Y, Taha MH, Al-Neel S, Gaffar AM. Students' perception of the learning environment and its relation to their study year and performance in Sudan. Int $J$ Med Edu. 2018;9:145-150. doi:10.5116/ijme.5af0.1fee

32. Al-Qahtani MF. Associations between approaches to study, the learning environment, and academic achievement. J Taibah Univ Med Sci. 2015;10(1):56-65. doi:10.1016/j.jtumed.2015.01.014

33. Mayya S, Roff S. Students' perceptions of educational environment: a comparison of academic achievers and under-achievers at Kasturba Medical College, India. Edu Health. 2004;17(3):280-291. doi:10.1080/13576280400002445

34. Benè KL, Bergus G. When learners become teachers: a review of peer teaching in medical student education. Fam Med. 2014;46 (10):783-787.

35. Knobe M, Münker R, Sellei RM, et al. Peer teaching: a randomised controlled trial using student-teachers to teach musculoskeletal ultrasound. Med Edu. 2010;44:148-155. doi:10.1111/j.13652923.2009.03557.x

36. Rashid MS, Sobowale O, Gore D. A near-peer teaching program designed, developed and delivered exclusively by recent medical graduates for final year medical students sitting the final objective structured clinical examination (OSCE). BMC Med Edu. 2011;11(1). doi:10.1186/1472-6920-11-11

37. Weyrich P, Schrauth M, Kraus B, et al. Undergraduate technical skills training guided by student tutors-analysis of tutors' attitudes, tutees' acceptance and learning progress in an innovative teaching model. BMC Med Edu. 2008;8. doi:10.1186/1472-6920-8-18 


\section{Publish your work in this journal}

Advances in Medical Education and Practice is an international, peerreviewed, open access journal that aims to present and publish research on Medical Education covering medical, dental, nursing and allied health care professional education. The journal covers undergraduate education, postgraduate training and continuing medical education including emerging trends and innovative models linking education, research, and health care services. The manuscript management system is completely online and includes a very quick and fair peer-review system. Visit http://www.dovepress.com/testimonials.php to read real quotes from published authors.

Submit your manuscript here: http://www.dovepress.com/advances-in-medical-education-and-practice-journal 